\title{
Nazipartiet i Medelby i 1943
}

\section{af Hans Schultz Hansen}

Efter det tyske sammenbrud i 1945 overtog Landsarkivet i Aabenraa en stor mængde arkivalier fra det tyske mindretals organisationer. Især daværende arkivar Peter Kr. Iversen udførte et stort arbejde for at redde disse arkiver, og han sørgede for en foreløbig ordning af de mange meter papirer. 11993 blev mindretallets arkiver nyordnet og en fortegnelse udgivet. Under dette arbejde er arkivar Hans Schultz Hansen stødt på et ringbind fra 1943 med sager fra »National-Sozialistische Deutsche Arbeiter-Partei«s (N.S.D.A.P.) »Ortsgruppe« i Medelby sogn umiddelbart syd for den dansk-tyske grænse. Arkivet kaster ikke nyt lys over nazitidens store forbrydelser og beretter ikke om dramatiske opgør med styrets modstandere, men viser dog i glimt, hvorledes dette afgørende år formede sig for partiarbejdet.

1943 var året, hvor den anden verdenskrig nåede til sit vendepunkt. I begyndelsen af november 1942 led Tyskland sit første alvorlige nederlag i slaget ved El Alamein. Winston Churchill spåede dengang forsigtigt, at selv om den britiske sejr ikke var enden på krigen og heller ikke begyndelsen på enden, så var den måske enden på begyndelsen.

Begivenhederne i 1943 forte ikke til krigens afslutning, men nu blev det klart, at Tysklands herredømme over Europa gik på hæld. Den 2. februar overgav de sidste omringede tyske tropper i Stalingrad sig til den røde hær. Godt to uger efter, den 18. februar, proklamerede propagandaminister Joseph Goebbels "den totale krig «. Endnu på dette tidspunkt var Tyskland bagefter Storbritannien i mobiliseringen af nationens ressourcer. Nu skulle der gøres en ekstra indsats på hjemmefronten. Den rakte imidlertid ikke til at forhindre flere tyske militære nederlag i foråret og sommeren 1943. I maj blev aksemagterne jaget ud af Afrika, og i juli invaderede de allierede Sicilien. Hitlers førerkollega Mussolini blev afsat, og efter invasionen på det italienske fastland i september faldt Italien helt fra som tysk allieret. På østfronten forsøgte den tyske hær forgæves modoffensiven "Zitadelle" ved Kursk, men den brød sammen i begyndelsen af juli, og dermed overgik initiativet definitivt til russerne.

I luftrummet fandt stadig flere britiske og amerikanske bombemaskiner vej til de tyske byer. I april begyndte evakueringen af befolkningen fra de bomberamte byer for alvor. Krigen rykkede nærmere den enkelte tysker, hans familie og hans hjemegn. Det mærkedes også allerøverst mod nord, i Medelby sogn umiddelbart syd for den dansk-tyske grænse. 


\section{Medelby sogn og N.S.D.A.P.}

Medelby ligger omkring $15 \mathrm{~km}$ vest for Flensborg på det magre slesvigske midtland. Sognet består af kirkebyen Medelby og landsbyerne Jarlund, Østerby, Holt, Vesby og Bøgslund. Det har ikke meget at byde turisten og havde det heller ikke dengang. En besøgende i 1933 hæftede sig dog ved udsigten fra det $54 \mathrm{~m}$ høje bjerg Lundtop: »Heroppe samler sig hele den storhed og ensomhed, man uvilkårlig gribes af, når man færdes i disse store grænsesogne ad ligegyldigt hvilken af de åbne, uendelige veje«.

I 1933 var egnens politiske landskab lige så uvarieret. Provinsen SlesvigHolsten var det område i Tyskland, hvor N.S.D.A.P. først opnåede det absolutte flertal af stemmerne ved et frit valg. Den brune bølge var især stærk i midtlandet, og dens skvulp nåede helt op til Medelby sogn. Ved rigsdagsvalget i juli 1932 fik N.S.D.A.P. $37 \%$ af stemmerne i Tyskland som helhed, men 51\% i Slesvig-Holsten og $65 \%$ i Sydtønder kreds. Inden for kredsen havde

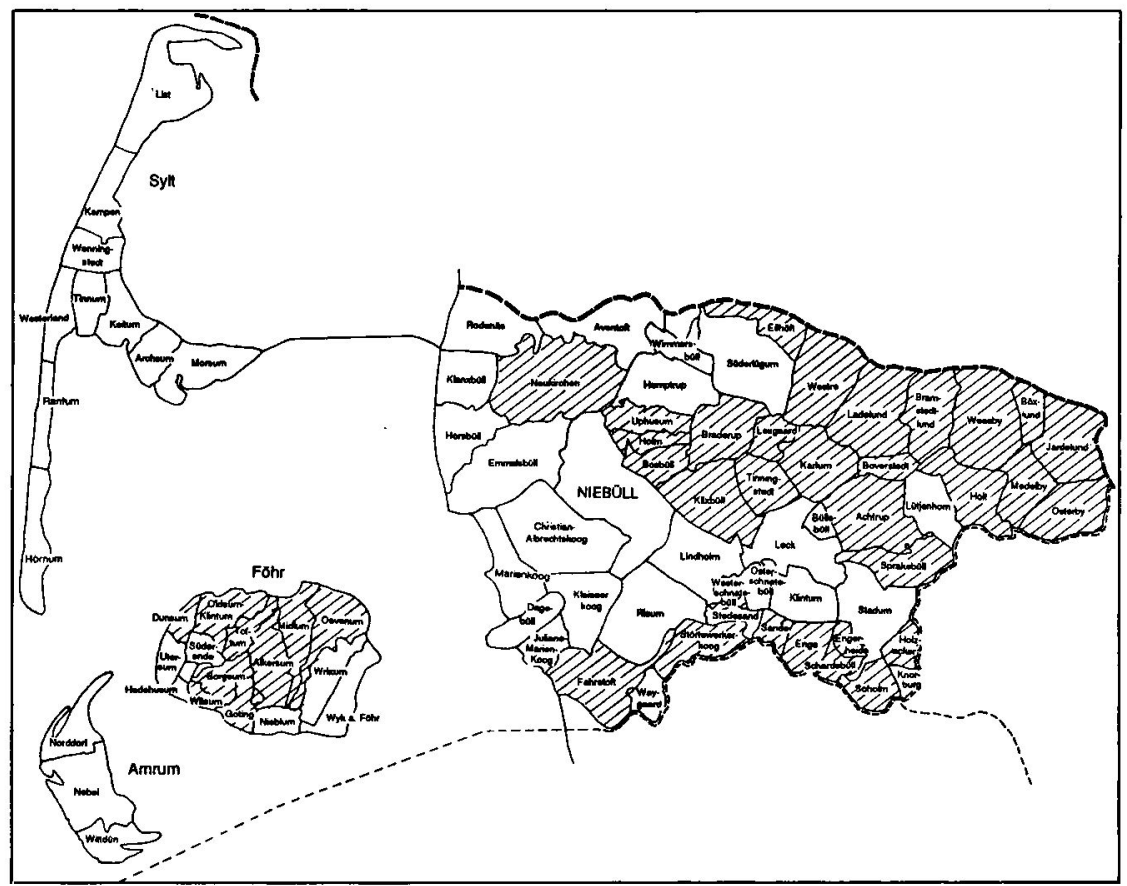

I Sydtønder amt opnåede N.S.D.A.P. massiv tilshutning ved rigsdagsvalget 31.juli 1932. Medelby horte til den lange rakke af valgdistrikter, hvor nazipartiet opnaede over $85 \%$ af stemmerne (her skraveret). Gengivet efter Wilhelm Koops: Südtondern in der Zeit der Weimarer Republik, 1993, s. 386. 
N.S.D.A.P. i 41 valgdistrikter ud af ialt 83 opnået $85 \%$ af stemmerne eller derover. Blandt disse stærkt nazistiske valgdistrikter var samtlige i Medelby sogn.

Denne klare bekendelse til den ekstreme tyske nationalisme gik i øvrigt hånd $\mathrm{i}$ hånd med, at endnu over $40 \%$ af befolkningen $\mathrm{i}$ Medelby sogn var dansktalende. Det dansksindede mindretals betydning var derimod forsvindende.

Der er givet mange forklaringer på nazismens triumftog i det sydslesvigske midtland. Landbrugskrisen slog hårdt $i$ disse ufrugtbare egne. Befolkningen var i ringe grad rodfæstet i Weimarrepublikkens tyske partipolitik og ikke så nært knyttet til demokratiet som deres standsfæller nord for grænsen. Derfor sluttede de hurtigt op omkring et radikalt protestparti som N.S.D.A.P. Nazisterne gjorde næppe meget konkret for bønderne, men de forsømte aldrig en lejlighed til at fortælle dem, at de var det tyske folks kerne. De sociale vilkår var beskedne, men samtidig forholdsvis lige, og det gjorde beboerne modtagelige for nazisternes agitation for folkefællesskabet. Endelig havde grænsekampen 1918-20 og den fortsatte antidanske stemning $\mathrm{i}$ Weimarårene pisket de nationale følelser op.

Efter ti år med Hitler stod nazismen fortsat stærkt. Den 1. maj 1943 fik N.S.D.A.P.s Ortsgruppenleiter Heinrich Davids besked på opgøre de mandlige partimedlemmers krigsindsats. Han nåede frem til, at 70 gjorde tjeneste i værnemagten, Waffen-SS eller andre militære formationer, 28 gjorde anden krigstjeneste, mens 110 hovedsagelig midaldrende og ældre mænd ikke var i trøjen. Der var med andre ord ialt 208 mandlige partimedlemmer, og det var mange sammenholdt med Medelby sogns samlede befolkning på 1409 indbyggere (1939).

Medlemstallet i de enkelte landsbyer fremgår af en "Generalmitgliederappell« den 31. oktober 1943. Det blev da opgiort til 163, sandsynligvis eksklusive de indkaldte soldater. Medlemmerne fordelte sig på fire "celler«: MedelbyHolt med 68 medlemmer, Østerby med 40, Vesby-Bøgslund med 35 og Jarlund med 19. Sammenlignet med indbyggertallet $i$ landsbyerne stod nazistpartiet lidt stærkere i de sydlige landsbyer Medelby, Holt og Østerby end i de nordlige Vesby, Jarlund og Bøgslund.

Medlemmernes erhverv afspejlede, at landbruget var sognets vigtigste næringsvej. De bevarede lister fra marts 1943 over samtlige »folkefæller« i Medelby sogn og deres oplysninger om de forskellige medlemskaber viser, at langt de fleste, omkring tre fjerdedele af partimedlemmerne og SA'erne var selvstændige landmænd eller bondesønner. Resten var håndværkere, tjenestemænd og arbejdere (se opgørelse i bilag). 


\section{Partiets aktiviteter}

Nazismen udviklede som andre politiske bevægelser med totalitære ambitioner sin egen kalender med særlige, årligt tilbagevendende festdage og højtideligheder. På trods af krigens skærpelse - eller på grund af den - blev dette program også afviklet i 1943.

Første mærkedag var tiåret for magtovertagelsen i 1933. Efter ordre fra kredsledelsen skulle den fejres med "Grosskundgebungen in allen Kreisen und Ortsgruppen « om aftenen den 29. januar og markeres på anden vis den 30. Programmet blev lagt på et møde mellem sognets »politische Leiter« den 25 .januar og omfattede faneindmarch, korsang af Bund deutscher Mädel, "Begrüssung«, et talekor ved Hitlerjugend, fællessang, oplæsning af citater fra Hitlers taler, en tale af landråd Dr. Fröbe, flere sange og til slut »Führergruss« og nationalsange. Dette forløb var typisk for mange af de nazistiske fester og

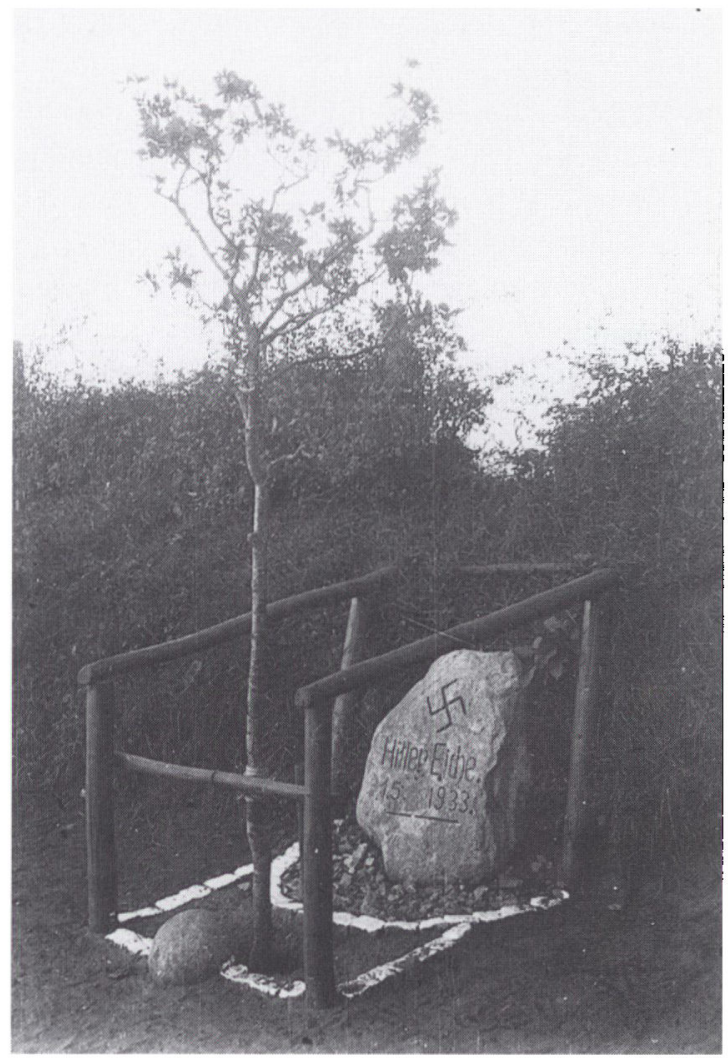

Nazificeringen antog mange former. I 1933 blev der plantet "Hitler-Eichen". I Langbjerg ost for Medelhy hlev traet plantet l. maj 1933 og det blev markeret med en mindesten. Foto Niels Kjems 1933. Arkivet ved Dansk Centralbibliotek for Sydslesvig P295-22. 
afspejlede deres kultiske præg. Formålet var ikke at give deltagerne rationel oplysning om de politiske forhold, men at give dem en følelsesmæssig oplevelse. Programmet rummede således adskillige elementer fra den protestantiske gudstjeneste. Den indledende hilsen svarede til indgangsbønnen, førercitaterne til tekstlæsningen, talen til præstens prædiken, talekoret til bøn og trosbekendelse. Som i kirken var der kor- og fællessang.

Blandt de førerguldkorn, som deltagerne i festen den 29. januar kunne tage med hjem, var der et, der viste, hvad Hitler regnede med kunne komme: "Der findes fjender, hvor der ikke gives pardon, hvor der kun gives en eneste mulighed: Enten falder vi, eller også falder fjenden «. Det blev som nævnt Stalingrad, der faldt, og den 25. februar måtte Ortsgruppeføreren på et medlemsmøde komme ind på denne nye situation: "Svære og sorgfulde uger ligger bag os. For første gang i denne krig har et tilbageslag ramt os. Vore tapre soldater måtte vige et stykke tilbage på grund af den bolsjevikiske kolos' enorme fremstormen«. Men nu var fronten stabiliseret, og den russiske offensiv havde kostet den røde hær dyrt: »Når vi tager de umenneskelige tab og ødelæggelser hos den bolsjevikiske hær $\mathrm{i}$ betragtning, som russeren måtte købe sin fremmarch med, så ligger der vel $i$ dette en fordel, som har bragt os den endelige sejr $\mathrm{i}$ østen et stykke nærmere«. Ortsgruppeføreren havde ikke mistet sin tro på Tysklands »Endsieg«.

Som andre totalitære bevægelser satsede nazismen stærkt på ungdommen. Den kunne lettere end de voksne præges og formes i den retning, ideologien krævede, så »det nationalsocialistiske menneske« kunne blive en realitet. Det var derfor med beklagelse, Ortsgruppefører Davids i januar måtte konstatere, at den lokale Hitlerjugend havde været passiv i tre måneder. Det var lykkedes Davids at få en toldsekretær fra Jarlund til at overtage hvervet som fører, men partiets og Hitlerjugends kredsledelse havde ikke bakket ham op, og det bad Davids nu om måtte ske. Der var efter hans mening $i$ hvert fald ikke noget $i$ vejen med drengene i Medelby: "Størstedelen af drengene i min Ortsgruppe er $i$ orden og forlanger en autoritær ledelse $\ll$.

Med de nazistiske forhåbninger til ungdommen kan det ikke undre, at partiets leder Martin Bormann forkyndte: »Verpflichtung der Jugend hører til en af de væsentligste højtideligheder i det tyske folkefællesskab«. Denne mærkedag bestod $i$, at de 14-årige medlemmer af Hitlerjugend og Bund deutscher Mädel skulle sværge troskab mod nationalsocialismen. I Medelby forløb festen den 28. marts efter det traditionelle skema med korsang, fællessang, taler og talekor med citater.

Efter festen forespurgte kredsskolingslederen for Sydtønder amt om foraldrenes indstilling. Ortsgruppeføreren kunne hertil svare, at den var positiv og at alle forældre havde deltaget ved højtideligheden. Såvidt det var ham 
bekendt, var festen dog kun i fire tilfælde tillige blevet fejret i hjemmet. Det store flertal anså stadig konfirmationen for hovedsagen. Kun 4 af de 24 unge edsaflæggere var ikke tilmeldt til konfirmation. Det skyldtes, at de unge "for størstedelen gjorde konfirmationen med efter tryk fra forældrene, som med eller uden overbevisning ikke ville bryde med denne nedarvede tradition«. Selv om nazismen som bevægelse havde vundet sejrrigt frem på den mellemslesvigske geest, var det altså endnu ikke lykkedes for dens ideologi at fortrænge de kristne forestillinger, $\mathrm{i}$ hvert fald ikke i den midaldrende og ældre generation.

Typisk for totalitære regimer er også den grænseløse lederkult. Adolf Hitlers fødselsdag den 20. april var derfor en anden stor festdag i den nazistiske kalender, vel den største. Rammerne omkring festen var de sædvanlige med faneindmarch, fællessang, citater og talekor. Et særligt indslag var optagelse af nye partimedlemmer, der aflagde følgende ed over for Ortsgruppeføreren som lokal »Hoheitsträger«: »Jeg lover min fører Adolf Hitler troskab. Jeg lover til enhver tid at imødekomme ham og de førere, han har givet mig, med agtelse og adlydelse«. Hovedpunktet var Ortsgruppeførerens tale, der naturligvis først og fremmest var en forherligelse af fødselsdagsbarnet: "Vi nationalsocialister har og vil altid have fuld tillid til føreren, vi kender dog førerens historiske mission, der regner med alle tænkelige muligheder. Da fjendtlige magter påtvang os krigen, viste det sig, at føreren forstod at løse spørgsmålet, om feltherren eller politikeren skulle bestemme. Der var ingen forskel mellem politiker og feltherre. Føreren forener i sig begge begavelser ... Dermed trådte han ind i den lille skare af mænd i verdenshistorien, som formår at repræsentere en hel nations totalitet ... Vi giver afkald på at spørge, hvor længe krigen endnu vil vare og hvilke opgaver, der ligger foran os: Vi har endnu efter hvert vundet slag spændt hjelmen strammere og ventet på nye befalinger fra foreren. Eet ved vi, at foreren vil føre os til sejr, at vi kæmper for en stor og hellig sag«.

Ortsgruppeføreren næunte Katynmassakren, som netop da blev kendt i Tyskland. 12.000 polske officerer var blevet likvideret af Sovjetmagten: „Man må tænke sig: 12.000 unge, værgeløse mennesker, som intet havde forøvet mod Rusland, har man regelret fort til slagtebænken og myrdet og ved siden af [indrettet et] forlystelseslokale for morderne. Mere djævelsk og klart kan det vel ikke føres os for øjne, hvad det galder om«. Det behøver næppe at tilføjes, at Ortsgruppeføreren helt forbigik de tyske forbrydelser mod polakkerne og andre folkeslag, som i tal forlængst overgik russernes i Katyn mangefold.

Den 16. maj var "Mors dag«, hvor mødre, der havde født mange børn, udmærkedes med regimets »Mutterkreuz«. Det skete ved en fest, arrangeret af NS-Frauenschaft med tale af Ortsgruppeføreren. I juni blev der holdt en "Schulungsabend « for partimedlemmerne. Årets næste store fest var høstfesten - "Erntedankfeier « - den 3. oktober, en traditionel landsbyfest, som parti- 


\title{
Im ITamen des \\ Deutjchen Dolfes \\ verleihe ich
}

\author{
die dritte 5 tufe \\ des \\ Ehrentrenzes \\ der Deutfchen Mntter
}

Berlin, den 21. Mai 1939

Der fïhrer und Reichsłanzler

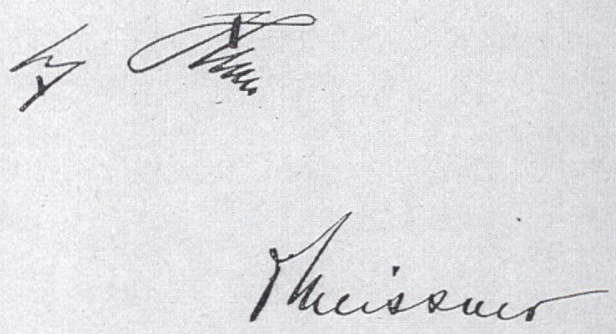

Modre med mange born blev hadret med et såkaldt "Mutterkreuz". Arkivet ved Dansk Centralbibliotek for Sydslesvig. 
et efter 1933 havde taget monopol på. Ortsgruppeføreren fik overrakt en "høstkrone« af den lokale distriktsbondefører og takkede i sin tale Hitler for, at han havde stillet sin bondestand under sikker beskyttelse, så den kunne bjerge høsten uberørt af krigen, og han takkede særlig de gamle, helt unge og kvinderne, som måtte udføre landbrugsarbejdet i mandens fravær. Helt uberørte af krigen var bønderne i Medelby altså alligevel ikke. Hovedtaleren var kredsleder Peperkorn, som dengang var kendt i Danmark for sine udfordrende ytringer i 1933 om revision af 1920-grænsen.

Festerne var en indramning af partihverdagen, som med den totale krig blev mere og mere brydsom. Under mobiliseringen af Tysklands ressourcer stod partiet således for en mængde indsamlinger. I januar blev der indsamlet til "Bauernspende« og »Handwerkerspende " og foretaget "Sammlung zur Solidarität«. Tilsammen indkom der i denne måned tat ved 6100 mark. Samme måned blev der samlet jern. I begyndelsen af juni var genstandene tøj og sko, hvor resultatet blev $760 \mathrm{~kg}$ tøj, $149 \mathrm{~kg}$ gammelt læder og 166 par sko. I september samledes 142 bøger til Wehrmacht. I oktober skulle der have været samlet til vinterhjælpen (»Winterhilfswerk $\lll$ ), men det blev for meget for Th. N. i Jarlund. Han nægtede og blev derfor beordret til at begrunde sin vægring for Ortsgruppeføreren, som bevidst kryptisk lod meddele: „Ellers vil jeg foranstalte videre«. Det ser dog ud til, at det ikke blev nødvendigt. Ved siden af det rent praktiske formål havde indsamlingerne utvivlsomt også en politisk side ved at holde medlemmerne i aktivitet og fă dem til at føle, at de gjorde en indsats for krigsførelsen, selv om de ikke stod i forreste linje ved fronterne.

\section{Krigen rykker nærmere}

Festtaler og indsamlingshverdag lod fornemme, at krigen var rykket nærmere, men dette viste sig også på anderledes håndfast vis. Den 27.januar fik alle "politiske ledere « i partiet besked på at opsøge hver enkelt husstand for at mobilisere helt eller delvis ledig arbejdskraft til indsats for rigets forsvar. Alle mænd $\mathrm{i}$ alderen 16-65 år skulle registreres, og kvinderne $\mathrm{i}$ alderen 17-45 år gik heller ikke fri. I Medelby sogn blev 25 kvinder registreret som duelige til arbejdstjeneste.

Partiet var ansvarligt for at underrette de pårørende, når en soldat var savnet eller faldet. I 1943 måtte Ortsgruppeføreren eller hans medhjælpere gå den tunge gang til forældre eller ægtefælle til 10 faldne, heraf de $8 \mathrm{i}$ andet halvår. Dertil kom 3 savnede. Det var hver gang et ubehageligt job.

I januar fik Davids brev fra en kaptajn i Luftwaffe, som han brevvekslede med. Kaptajnen glædede sig over nyheder fra hjemegnen, dog med en undta- 
gelse: "Meddelelserne om de faldne bondesønner fylder mig dog altid med særlig smerte. Jeg må altid fastholde, at krigens hovedbyrde bliver båret af den tyske bondestand, hvad enten det er ved det møjsommelige og tunge arbejde, eller ved ofringen af det bedste tyske blod, overalt står bonden i forreste front! Denne under fjendens ild hærdede og bittert prøvede bondeslægt vil også blive den ædle og sande nationalsocialistiske idés kraftkilde«. Kaptajnen, der selv havde måttet gennemgå fire operationer, havde altså ikke glemt "Blut und Boden« ideologien og så iøvrigt frem til, efter endnu en lille operation, til sommer atter at komme til at sidde ved en flyvemaskines styrepind.

De huller $\mathrm{i}$ fronten, som var varige, måtte udfyldes ved en stadig stærkere mobilisering. Ortsgruppeføreren fik derfor den 14. marts ordre til at udfærdige lister over alle mænd $i$ alderen 16-65 år. Begrundelsen var, at »den nuværende situation gør den nøjagtigste opgørelse over alle endnu eksisterende reserver af mænd nødvendig. Væddeløbet mellem alle underorganisationer og korps om det enkelte menneske må endegyldigt være forbi. Fra nu af er det foruden værnemagten kun partiet, som registrerer og styrer. « Nazistyrets mange modstridende organer og kompetencer skulle altså vige for en strammere administration. Partiets egen efterlevelse af parolen var det vist så som så med. Øjensynligt forsøgte det at hytte sine egne wehrenamtliche politische Leiter«. I december fik Ortsgruppeførerne i hvert fald besked på, at de straks skulle melde det til kredsledelsen, hvis de fik en indkaldelse.

De, der ikke kunne bruges ved fronten, skulle gøre tjeneste som vagtmænd, hjælpepoliti, brandmænd, ved antiluftskytset osv. Netop antiluftskytset fik mere og mere travlt. I det nordligste Tyskland blev Hamborg og Kiel gentagne gange bombet af britiske og amerikanske fly. Natten til den 31.januar og 4. februar angreb RAF Hamborg, og den 14. maj og 13.juni blev Kiel offer for amerikanske angreb. Kendt er angrebet på Hamborg i slutningen af juli og begyndelsen af august, hvor RAF bombede om natten og det amerikanske luftvåben om dagen. Her var bombardementet så kraftigt, at en ildstorm opstod og dræbte tusinder. Næste større angreb fandt sted den 13. december mod Kiel og Hamborg.

Denne krig i luftrummet over Tyskland fik også følger i Medelby. I marts blev to partifæller udnævnt til at overvåge mørklægningen og melde overtrædelser til Ortsgruppeføreren. Evakuerede fra de store byer blev indkvarteret på landet. I Medelby var der ikke mange fra Hamborg, men desto flere kom der fra Kiel. I begyndelsen af september blev en flok udbombede kielere indkvarteret, 33 i Medelby, 10 i Bøgslund, 18 i Holt, 30 i Jarlund og 26 i Østerby.

De mange fremmede gav anledning til kultursammenstød og konflikter. Et cirkulære fra kredsledelsen i november fremhævede ganske vist, at størstedelen af indkvarteringerne forløb godt og at flertallet af de evakuerede var tilfredse 
med de fastboendes gæstfrihed. I den sidste tid var der dog fra de evakuerede kommet klager, som for en del var korrekte. Nogle evakuerede var straks ved ankomsten blevet uvenligt modtaget. Det var sket, at de havde måttet gå fra sted til sted, før de havde fået kvartér. Dette kunne være et karlekammer, mens de fastboende beholdt den fine stue til brug for gæstebud. Gæsterne havde nogle steder måttet vaske sig sammen med den udenlandske arbejdskraft (krigsfanger). Det var forekommet, at man havde forlangt fuld arbejdsindsats på lige fod med landarbejderne, mens kosten derimod var ringere, og nogle kvarterværter havde bevidst behandlet de evakuerede dårligt for at få dem til at flytte. Kredsledelsen slog fast: "I denne tid, hvor vi alle må rykke sammen for at bære den os pålagte skæbne i fællesskab, er der ikke mere rum for borgerlig gemytlighed og særønsker«. Det var op til Ortsgruppeførerne at sørge for en gnidningsfri evakuering.

Også Medelby havde sine modsætninger mellem fastboende og evakuerede. M. B. i Jarlund husede en dame fra Kiel og hendes to børn, som hun beskyldte for at stjæle fedt, sukker, kul, lagner og æg. Ortsgruppeføreren og borgmesteren i Jarlund undersøgte sagen og fik ikke indtryk af, at damen fra Kiel var en tyv. Til kredslederen skrev førstnævnte, at fru B. havde gjort alt for at blive fri for indkvarteringen.

Familien I. i Medelby husede ligeledes en dame fra Kiel, som meldte til Ortsgruppeføreren, at værterne havde en negativ indstilling til regeringens forholdsregler. Det gav anledning til en mundtlig og en skriftlig advarsel fra Ortsgruppeføreren, der i sidstnævnte skrev: "Forefalder der én gang til noget, vil jeg melde hele sagen og sørge for, at De fra højere sted bliver stillet grundigt til regnskab. Hvad det betyder for Dem, vil være Dem klart«.

\section{Kontrol, disciplin, stemningspåvirkning}

Dette brev viser, at Ortsgruppeføreren vidste at spille på en af det totalitære samfunds hyppigst benyttede tangenter: angsten for det ukendte. Usikkerheden om hele situationen kunne dog også vende sig mod styret. Flere gange fik Ortsgruppeførerne besked på at modvirke omløbende rygter. Overflødig snak om, hvornår og med hvilke våben, Tyskland ville gengxlde bombningen, skulle således undgås - af nærliggende årsager. Befolkningens uro på grund af mønstringen af årgangene 1884-93 (de 50-60 årige) skulle dæmpes ved at understrege, at de kun skulle gøre indsats i hjemstavnen. Det var heller ikke rigtigt, at paven skulle fjernes fra Rom og at evakueringen af børnene til landområderne (»Kinderlandverschickung) havde som formål, at partiet og staten skulle overtage opdragelsen af de små i stedet for forældrene. Ligeledes var det løse ryg- 
ter, når det blev påstået, at de allierede nedkastede flyveblade med oplysninger om, hvilke byer, der skulle bombes. Ortsgruppeførerne fik også besked på gennem "mundpropaganda" at orientere radiolytterne om, hvorfor der blev indført underlægningsmusik til nyhederne kl. 22. Det var for at hindre fjendtlig "indbrydning « i programmet med egne nyheder.

De totalitære regimers teknik består $i$ sidste instans $i$, at befolkningen ved så lidt som muligt om magthaverne, disse til gengxld mest muligt om hvert enkelt menneske. Det afspejles også i papirerne fra Ortsgruppeføreren i Medelby, som besvarede mange personforespørgsler. Skulle et ungt menneske have lån til uddannelse, et ungt par lån til at indgå ægteskab og sætte bo eller børnepenge, et barnløst ægtepar en adoption, en ansøger en stilling i det offentlige eller partiet, ubemidlede en radio, en landmand en arbejderske østfra, en bonde et lån til etablering, en dygtig eller trofast person en hædersbevisning - så skulle Ortsgruppeføreren gøre anmærkning om vedkommendes politiske sindelag før og efter nazisternes magtovertagelse i 1933, om medlemskab af diverse nazistiske organisationer, om »Gebefreudigkeit « ved indsamlinger til National-Sozialistische-Volkswohlfahrt og Winter-Hilfs-Werk samt om den pågældendes menneskelige karakter. I rubrikken "Politisch vor und nach der Machtübernahme« skrev Ortsgruppefører Davids i to tilfælde "Vorkämpfer« eller »Mitarbeiter der Bewegung «. En Hitlerjugendfører fik uddybende ord med på vejen: »B. M. ist zur Partei und zum Staat voll und ganz bejahend eingestellt«. I syv tilfælde anførtes det mere beskedne »mit der Bewegung«. Otte gange skelnede han mellem tiden før og efter januar 1933, idet ansøgernes politiske stilling før magtovertagelsen blev betegnet som "neutral«, efter 1933 som "mit der Bewegung «. Kun i to tilfælde var ansøgere forblevet neutrale efter 1933. Modstandere var der ingen af, men de havde velsagtens på forhånd opgivet at søge stillinger eller hjælp.

Sindelagskontrollen kunne udarte til direkte angiveri. En ivrig lærer i partiets tjeneste anmeldte således et tilfælde af aflytning af udenlandsk radio, som Ortsgruppeføreren overgav til statsadvokaten, men ifølge Ortsgruppeføreren var der på grund af »Haltlosigkeit« intet sket. Aflytning af fjendtlige radioer kunne i det nazistiske Tyskland føre til dødsstraf, så det var en alvorlig sag, som altså til held for den pågældende lytter ikke blev fulgt op. Mindre alvorligt var det, at tre partimedlemmer blev indberettet til kredsledelsen på grund af manglende disciplin. De var ikke mødt op ved medlemsappellen den 31, oktober og havde ingen undskyldning. Endda den stedfortrædende »Blockleiter« $\mathrm{i}$ Holt var udeblevet uden varsel.

At tolke disse tre udeblivelser ud af 163 som begyndende opløsning vil være fejlagtigt. Tvært imod giver hele sagsmappen fra 1943 indtryk af et lokalt partiapparat, som fungerede videre og her som i Tyskland generelt endda fik 
større magt og betydning efter proklameringen af den totale krig. Vel blev de tyske sejre fra 1943 afløst af nederlag, men det tyske samfund havde endnu mange materielle og menneskelige ressourcer at mobilisere, nok til yderligere to års krig.

\section{BILAG}

Medlemmer af N.S.D.A.P. og dets "Sturmabteilung" (S.A.):

\begin{tabular}{|lcc|}
\hline & N.S.D.A.P* & S.A.** \\
\hline Landbruger & $72 \%$ & $81 \%$ \\
Håndværker & $7 \%$ & $10 \%$ \\
Arbejder, landarbejder & $2 \%$ & $3 \%$ \\
Offentlig ansatte & $15 \%$ & $4 \%$ \\
Andre og uden angivelse & $4 \%$ & $1 \%$ \\
\hline Ialt & $100 \%$ & $100 \%$ \\
Antal & 46 & 69 \\
\hline
\end{tabular}

* Kun angivet for Østerby, Medelby, Holt og Bøgslund.

** Kun angivet for Jarlund og Holt.

\section{UTRYKTE KILDER}

Landsarkivet for Sønderjylland, Aabenraa: Det tyske mindretals arkiver nr. 1266, N.S.D.A.P. Ortsgruppe Medelbys sager 1943.

\section{LITTERATUR}

Hans Schultz Hansen: Det tyske mindretals arkiver 1920-1945. Aabenraa 1993.

Rud. Heberle: Landbevölkerung und Nationalsozialismus. Stuttgart 1963.

Ole Helmer Jensen: 2. Verdenskrigs hvornår skete det. København 1985.

Franz von Jessen: Haandbog i det slesvigske Spørgsmaals Historie, III, København 1938.

Wilh. Koops: Südtondern in der Zeit der Weimarer Republik. Neumünster 1993.

George L. Mosse: Die Nationalisierung der Massen. Politische Symbolik und Massenbewegung in Deutschland von den Napoleonischen Kriegen bis zum Dritten Reich. Frankfurt a.M./Berlin 1976.

Knud Olrik: En Tur gennem Mellemslesvigs Hedeegne. I: G. Knudsen og K. Kretzschmer (udg.): Sydslesvig. Hedeegnene mellem Angel og Frisland. Kobenhavn 1933.

Aage Trommer: Den store alliance 1941-45. København 1989. 